\title{
Ketepatan Transfusi Pasien Thalasemia $\beta$ mayor Berdasarkan Tingkat Pengetahuan Orangtua di RSU Tangerang
}

\author{
Ema Hikmah*, Endang Suartini*, Een Sukaedah*
}

\begin{abstract}
Abstrak
Pengetahuan orangtua tentang merawat anak dengan thalasemia sangat diperlukan dalam upaya melakukan pencegahan secara dini terjadinya komplikasi yang dapat terjadi pada anak dengan thalasemia. Penelitian ini bertujuan untuk mengetahui hubungan pengetahuan orangtua tentang merawat anak thalasemia dengan ketepatan transfusi. Penelitian ini menggunakan metode penelitian analitik dengan desain penelitian crossectional dimana didapatkan jumlah responden sebanyak 97 orang. Analisis data dalam penelitian ini menggunakan uji chi-square. Hasil penelitian menunjukkan ada hubungan antara pengetahuan orangtua tentang perawatan anak thalasemia dengan ketepatan transfusi dengan nilai signifikan 0,000 ( $\mathrm{p}$ value $<0,05$ ), dan orangtua dengan pengetahuan yang baik akan memiliki kecenderungan 5,595 kali melakukan transfusi dengan tepat waktu. Melihat hasil yang signifikan bahwa ada hubungan antara pengetahuan orangtua tentang merawat anak thalasemia dengan ketepatan transfusi maka disarankan bahwa tenaga kesehatan secara kontinu melakukan penyuluhan untuk meningkatakn pengetahuan baik bagi orangtua maupun anak yang thalasemia.
\end{abstract}

Kata Kunci : Pengetahuan, ketepatan transfusi, thalasemia $\beta$ mayor.

\begin{abstract}
Abstact
Parents' knowledge about caring for a child with thalassemia is needed in order to perform early prevention of complications that can occur in children with thalassemia. This study aims to determine the relationship of parental knowledge about caring for a child with thalassemia with transfusion accuracy. This research used analytic study with cross-sectional design and found 97respondents. Data analysis in this study is done by using the chi-square test.There is a significant relation between parents' knowledge about child care with the accuracy of transfusion in thalassemia and it has significant value of 0.000 ( $p$ value <0.05), and parents with good knowledge will have5,595 timesbetteraccuracy in transfusion.Therefore it is suggested that health workers continue doing counseling to improvetheknowledge for both parents and children with thalassemia.
\end{abstract}

Key Word: Knowledge, transfusion accuracy, thalassemia $\beta$ major.

\section{Pendahuluan}

Indonesia merupakan salah Indonesia adalah sekitar $3-8 \%$, di satu negara yang memiliki penduduk pembawa talasemia, dimana frekuensi pembawa talasemia di beberapa daerah mencapai $10 \%$, artinya bahwa $3-8 \%$ dari 100 penduduk merupakan pembawa gen 
talasemia, dimana angka kelahiran rata-rata $23 \%$ dengan jumlah populasi penduduk sebanyak 240 juta diperkirakan akan lahir 3000 bayi pembawa gen tiap tahunnya ( Bulan, 2009)

\section{Keberhasilan penanganan} talasemia dapat mencegah kecepatan timbulnya komplikasi. Tanpa penatalaksanaan yang baik maka komplikasi yang terjadi akibat anemia akan berpengaruh terhadap gangguan tumbuh kembang dan anak sulit untuk mencapai usia sampai 20 tahun. Data menunjukkan bahwa 71 $\%$ pasien meninggal akibat gagal jantung kongesti sebagai dampak dari kerusakan organ akibat penumpukan zat besi (Wahyuni, 2009).

Sebagian besar pasien talasemia adalah pasien anak, oleh karena itu penatalaksanaan anak talasemia ini akan banyak bergantung pada orangtua.

Keberhasilan penanganan talasemia sangat erat kaitannya dengan pengetahuan orangtua mengenai perawatan yang baik mengenai nutrisi, mengenal tanda-tanda anemia dan pengaturan pola aktifitas yang disesuaikan dengan kondisi anak tersebut. Hal yang perlu diinformasikan lagi kepada anak adalah memilih jenis permainan yang meminimalkan penggunaan energi. Anak yang menderita talasemia harus diupayakan untuk melakukan aktifitas yang tidak menguras tenaga, bermain dan beristirahat dengan tenang serta melakukan aktifitas fisik yang sesuai dengan kemampuan (Wong, 2004).

Berdasarkan latar belakang diatas dilakukan penelitian mengenai hubungan pengethuan orangtua mengenai perawatan anak dengan thalasemia $\beta$ mayor dengan ketepatan transfusi di RSU Tangerang.

\section{Metode Penelitian}

Penelitian ini merupakan penelitian kuantitatif dengan menggunakan desain penelitian cross sectional. Data dianalisis menggunakan analisis bivariat chisquare.

Kegiatan penelitian ini menggunakan alat ukur berupa kuesioner untuk mengetahui pengetahuan orangtua mengenai pengetahuan orangtua 
tentang merawat anak dengan thalasemia, dan lembar observasi untuk mengetahui ketepatan transfusi.

Analisis data dalam penelitian ini diolah dengan program statistik. Analisis dilakukan univariat dan bivariat. Analisis univariat untuk mengetahui nilai dari pengetahuan orangtua dan ketepatan transfusi. Analisis bivariat digunakan menggunakan uji chi-square, untuk mengetahui hubungan pengetahuan orangtua dengan ketepatan transfusi.

\section{Hasil}

Selama pengumpulan data yang dilakukan mulai Mei Nopember 2013 didapatkan bahwa orangtua yang pengetahuannya baik sebanyak 76 orang atau $78,4 \%$.

Tabel 1

Distribusi Responden berdasarkan Pengetahuan Orangtua tentang Perawatan Anak dengan Thalasemia di Ruang Thalasemia RSU Tangerang tahun 2013

\begin{tabular}{ccc}
\hline Pengetahuan & Frekuensi & Persentase \\
& & $\%$ \\
\hline Baik & 76 & 78,4 \\
Buruk & 21 & 21,6 \\
\hline Total & 97 & 100 \\
\hline
\end{tabular}

Tabel 1.Hasilanalisispengetahuan padaorangtua dengan anak thalasemia $\beta$ mayor di RSU Tangerang terhadap 97 orang respondenmemperlihatkanpengetahu an orangtua dengan pengetahuan baik sebanyak 76 orang atau $78 \%$ dan pengetahuan orangtua yang buruk tentang perawatan anak dengan thalasemia sebanyak 21 orang atau 21,6\%. Hasil tersebut memperlihatkan bahwa sebagian besar orangtua mempunyai pengetahuan yang baik tentang perawatan anak dengan thalasemia di RSU Tangeran

Tabel 2

Distribusi Responden berdasarkan Ketepatan transfusi di RSU Tangerang tahun 2013

\begin{tabular}{ccc}
\hline $\begin{array}{c}\text { Ketepatan } \\
\text { Transfusi }\end{array}$ & Frekuensi & Persentase \% \\
\hline Tepat & 74 & 76,2 \\
Tidak tepat & 23 & 23,8 \\
\hline Total & 97 & 100 \\
\hline
\end{tabular}

Tabel2.Hasilanalisisketepatan transfusi pada anak thalasemia $\beta$ mayor di RSU Tangerang terhadap 97 orang respondenmemperlihatkanyang melakukan transfusi secara tepat sebanyak 74 orang atau $76 \%$, sedangankan responden yang melakukan transfusi tidak tepat 
sebanyak 23 orang atau 23,8. Hasil ini menunjukkan bahwa sebagian responden melakukan transfusi secara tepat pada anaknya yang thalasemia di RSU Tangerang.

\section{Tabel 3}

HubunganPengetahuan Orangtua tentang

Perawatan Anak Thalasemia $\beta$ Mayor

terhadap Ketepatan Transfusi di RSU

Tangerang Tahun 2013

\begin{tabular}{|c|c|c|c|c|c|}
\hline $\begin{array}{l}\text { Penget } \\
\text { ahuan }\end{array}$ & \multicolumn{2}{|c|}{$\begin{array}{l}\text { Ketepatan } \\
\text { Transfusi }\end{array}$} & $\begin{array}{l}\text { To } \\
\text { tal }\end{array}$ & $\begin{array}{c}\text { OR } \\
95 \% \mathrm{CI}\end{array}$ & $\begin{array}{c}\mathrm{P} \\
\text { value }\end{array}$ \\
\hline & $\begin{array}{c}\text { Tepat } \\
(\%)\end{array}$ & $\begin{array}{c}\text { Tdk } \\
\text { tepat } \\
(\%)\end{array}$ & & & \\
\hline Baik & $\begin{array}{c}72 \\
(97,3)\end{array}$ & $4(2,7)$ & 76 & $\begin{array}{c}5,595 \\
(2,294- \\
13,644)\end{array}$ & $\begin{array}{c}0,00 \\
0\end{array}$ \\
\hline Buruk & $\begin{array}{c}2 \\
(2,7 \%)\end{array}$ & $\begin{array}{c}19 \\
(82,6)\end{array}$ & 21 & & \\
\hline Total & $74(100)$ & $\begin{array}{c}23 \\
(100)\end{array}$ & 97 & & \\
\hline
\end{tabular}

Dari Tabel 3. Analisis hubungan pengetahuan orangtua dengan ketepatan transfusi pada anak thalasemia $\beta$ mayor di RSU Tangerang didapatkan hasil 76 orang dengan pengetahuan baik melakukan transfusi secara tepat sebanyak 72 orang atau 97,3\%, sedangkan pengetahuan orangtua yang buruk sebanyak 23 orang melakukan transfusi secara tidak tepat sebanyak 19 orang atau $82 \%$. Pada analisis diatas terdapat hubungan antara pengetahuan orangtua merawat anak dengan thalasemia dengan ketepatan transfusi, dengan $\mathrm{P}$ value sebesar $0,000(\alpha=0,05)$. Dari hasil analisi dapat disimpulkan bahwa orangtua dengan pengetahuan baik mempunyai kecenderungan sebanyak 5,595 kali untuk melakukan transfusi dengan tepat.

\section{Pembahasan}

Pengetahuan orangtua tentang perawatan anak thalassemia $\beta$ mayor yang baik berhubungan dengan ketepatan transfusi. Analisis hubungan pengetahuan orangtua dengan ketepatan transfusi pada anak thalasemia $\beta$ mayor di RSU Tangerang didapatkan hasil 76 orang dengan pengetahuan baik melakukan transfusi secara tepat sebanyak 72 orang atau 97,3\%, sedangkan pengetahuan orangtua yang buruk sebanyak 23 orang melakukan transfusi secara tidak tepat sebanyak 19 orang atau $82 \%$. Pada anlisis ditas terdapat hubungan antara pengetahuan orangtua merawat anak dengan thalasemia dengan ketepatan transfusi, dengan $\alpha<0,05$ ( $\mathrm{p}$ value 0,000). Dari hasil analisi dapat disimpulkan bahwa orangtua dengan pengetahuan baik mempunyai 
kecenderungan sebanyak 5,595 kali untuk melakukan transfusi dengan tepat.

Penelitian tentang pengetahuan talasemia pernah dilakukan oleh Lee, Lin \& Tsai (2007) dengan hasil ada hubungan yang signifikan antara pengetahuan talasemia dengan kepatuhan menjalani program terapi.

Kondisi pengetahuan ini sangat berperan dalam membentuk sikap positif atau sikap negatif seseorang.Pengetahuan atau kognitif merupakan domain yang sangat penting dalam membentuk tindakan seseorang (Notoatmodjo, 2003).Kecenderungan tindakan pada kondisi pengetahuan yang baik adalah mendekati, menyenangi, mengharapkan obyek tertentu, sedangkan kecenderungan tindakan pada sikap negatif adalah menjauhi, menghindari, membenci, tidak menyukai obyek tertentu.Sikap seseorang terhadap suatu objek adalah perasaan mendukung atau memihak maupun perasaan tidak mendukung atau tidak memihak pada objek secara spesifik (Azwar, 2011). Keberhasilan penanganan talasemia dapat mencegah kecepatan timbulnya komplikasi. Tanpa penatalaksanaan yang baik maka komplikasi yang terjadi akibat anemia akan berpengaruh terhadap gangguan tumbuh kembang dan anak sulit untuk mencapai usia sampai 20 tahun. Data menunjukkan bahwa 71 $\%$ pasien meninggal akibat gagal jantung kongesti sebagai dampak dari kerusakan organ akibat penumpukan zat besi (Wahyuni, 2009).

Sebagian besar pasien talasemia adalah pasien anak, oleh karena itu penatalaksanaan anak talasemia ini akan banyak bergantung pada orangtua. Keberhasilan penanganan talasemia sangat erat kaitannya dengan pengetahuan orangtua mengenai perawatan yang baik mengenai nutrisi, mengenal tandatanda anemia dan pengaturan pola aktifitas yang disesuaikan dengan kondisi anak tersebut. Hal yang perlu diinformasikan lagi kepada anak adalah memilih jenis permainan yang meminimalkan penggunaan energi. Anak yang menderita talasemia harus diupayakan untuk melakukan aktifitas yang tidak menguras tenaga, bermain dan beristirahat dengan 
tenang serta melakukan aktifitas fisik yang sesuai dengan kemampuan (Wong, 2004).

Keluarga berperan secara psikososial dengan membantu mengontrol perilaku anak membantu anak menghadapi perubahan secara fisik dan psikologis. Hasil dari penelitian tersebut pernah pula diungkapkan oleh Newland (2008) bahwa hubungan orang tua dan anak secara langsung berpengaruh dengan kondisi sakit anak dan kemampuan mengatur perilaku terhadap perubahan yang terjadi selama sakit. Fenomena yang pernah ditemukan oleh peneliti di rumah sakit, seorang anak talasemia datang ke rumah sakit dengan kondisi yang sangat memprihatinkan yaitu dengan kadar $\mathrm{Hb}$ yang sangat rendah $3 \mathrm{~g} / \mathrm{dl}$. Haemoglobin yang kurang dari 7 g/dl dapat mempengaruhi fungsi organ tubuh terutama otak karena tidak teroksigenasi dengan baik. Untuk itu orang tua perlu mengetahui tanda dan gejala anak talasemia apabila kondisi $\mathrm{Hb}$ nya sangat rendah yaitu lemas, pucat, dan kebiruan di mukosa bibirnya.

\section{Simpulan}

Berdasarkan hasil penelitian hubungan antara pengetahuan orangtua tentang cara perawatan anak thalasemia dengan ketepatan transfusi, dapat disimpulkan bahwa, pengetahuan pada orangtua dengan anak thalasemia $\beta$ mayor di RSU Tangerang terhadap 97 orang respon dengan pengetahuan baik sebanyak 76 orang atau $78 \%$ dan pengetahuan orangtua yang buruk tentang perawatan anak dengan thalasemia sebanyak 21 orang atau $21,6 \%$, sedangkan ketepatan transfusi pada anak thalasemia $\beta$ mayor di RSU Tangerang terhadap 97 orang responden memperlihatkan yang melakukan transfusi secara tepat sebanyak 74 orang atau $76 \%$, sedangankan responden yang melakukan transfusi tidak tepat sebanyak 23 orang atau 23,8. Hasil ini menunjukkan bahwa sebagian responden melakukan transfusi secara tepat pada anaknya yang thalasemia di RSU Tangerang, sehingga penelitian ini menunjukkan bahwa ada hubungan antara pengetahuan orangtua dengan ketepatan transfusi pada anak thalasemia $\beta$ mayor di RSU dengan nilai signifikan $0,000 \quad(p$ value 
$<0,05)$. Dari hasil analisis dapat disimpulkan bahwa orangtua dengan pengetahuan baik mempunyai kecenderungan sebanyak 5,595 kali untuk melakukan transfusi dengan tepat.

\section{Daftar Pustaka}

Arikunto, S. 2006. ProsedurPenelitianSuatuPendekat anPraktik. EdisiRevisi 6. Jakarta PT. RinekaCipta.

Bulan, S. 2009. Faktor-faktor yang berhubungan dengan kualitas hidup anak talasemia beta mayor. eprints.undip.ac.id/24717/1/Sandr a_Bulan.pdf , diunduh pada tanggal 18 Pebruari 2013

Johari S, Karimi M. 2008.

Socioeconomic and cultural factors affecting family planning among families of thalassemic children in Southern Iran. http://yith.ir/download/ejtemaei/n um10.pdf, diakses tanggal 18 Februari 2013

Hockenberry, M.J. \& Wilson, D. (2009). Wong Essensials of
Pediatric Nursing. Philadelphia: Mosby Elsevier.

Lee, Y.L, D.T. \& Tsai, S.F. (2008). Disease Knowledge and treatment adherence among patient with thalasemia major and their mothers in Taiwan, Journal of clinical, 18, 529-538

Sugiyono.MetodePenelitianKuantitat ifdanKualitatif Dan R \& D. cetakanke 7. CV Alfabeta. Bandung. 2009.

Wahidiyat PAW. Problem and management of thalassemia in Jakarta. Department of child health FKUI. PIT Yogyakarta. 2007.

Wahidiyat I. Thalassemia dan penanganannya. Dalam: Perkembangan mutakhir penyakit hematologi onkologi anak. Naskah Lengkap pendidikan tambahan berkala Ilmu Kesehatan Anak, Jakarta: Bagian Ilmu Kesehatan Anak XVI. Jakarta: FKUI,1991;109-12.

Wahyuni, S. (2009) Tahalsemia Mayor: Waspadai Jika wajah Balita terlihat Pucat diunduh dari http://www.suarakarya.online.com 